\title{
U.S. Troops and Foreign Economic Growth
}

\author{
Garett Jones \\ Center for Study of Public Choice \\ George Mason University \\ Tim Kane \\ Ewing Marion Kauffman Foundation
}

This version: February 2011

Forthcoming, Defence and Peace Economics

\begin{abstract}
Do American troops help or hinder economic growth in other countries? We use a newly constructed dataset of the deployment of U.S. troops over the years 19502000, and discover a positive relationship between deployed troops and host country economic growth, robust to multiple control variables. Each tenfold increase in U.S. troops is associated with a one-third percentage point increase in average host country annual growth. We explore three possible causal explanations: a Keynesian aggregate demand boost, the diffusion of institutions, and security. Extensive econometric testing, including the use of panel data, confirms the core relationship. The relationship is strongest in the poorest countries.
\end{abstract}

JEL Classification: C5, F42, O2, O4, O57

Keywords: Economic growth; U.S. military; national security

\footnotetext{
The authors would like to thank Jake Bartolomei, William Beach, Ike Brannon, James Carafano, William Casebeer, James Hamilton, Robert Litan, David Lyle, Greg Mankiw, Donald Marron, Mike Meese, John Nye and seminar participants at West Point for helpful comments. Jon Casale and Christine Leming provided research support. All mistakes are the authors' alone.
} 


\section{INTRODUCTION}

Do American troops help or hinder economic growth in other countries? The deployment of hundreds of thousands of U.S. military forces throughout the Middle East nearly a decade after $9 / 11$, long after the initial missions were accomplished, is often justified on an assumption that these troops are necessary for development. Afghanistan was invaded in 2001 to change the Taliban regime and displace al-Qaeda. Iraq was invaded in 2003 to change the Hussein regime and prevent possible usage of weapons of mass destruction. Should U.S. troops remain in both countries in such large numbers? For an economist, this reduces to a simple and quantifiable question of improving living conditions, commonly measured in terms of per capita income. This paper examines a newly constructed dataset covering U.S. troop deployments since 1950 and finds that such deployments have significant, positive impacts on economic growth rates in host countries, results that are robust to other known causes of growth.

This question could not be addressed without solid data on country-by-country U.S. troop deployments as well as comparable per capita income. We utilize a new dataset assembled by Kane (2004) documenting the deployment of U.S. troops to foreign countries over the years 1950-2000, based on U.S. Department of Defense records, which covers all countries of the world. The dependent variable used is annual growth in real gross domestic product per capita (GDPP) described by the Penn World Tables (Mark 6.1). GDPP data is available for 94 countries going back to 1960 .

Recent large-scale deployments to Iraq and Afghanistan obscure the fact that U.S. forces remain widely deployed elsewhere, as they have been every year since 1945. In 
fact, the absolute number of U.S. forces deployed overseas has held steady at around 400,000 since the year 2001 , fewer than the norm during the latter $20^{\text {th }}$ century. During the 1950s, an average of 730,000 U.S. soldiers were based abroad, rising to 762,000 during the 1960 s, then falling to $502,000,447,000$ and 269,000 during the $1970 \mathrm{~s}, 80 \mathrm{~s}$, and 90s respectively. Almost every nation on earth hosted American forces to some degree, with 181 of the 185 nations in the Kane (2004) dataset hosting some U.S. troops. During any given decade, 26-49 countries hosted more than 100 troops per year every year. Figure 1 shows annual U.S. troop levels in five different global regions. These numbers require any analysis of troop effects to look beyond binary comparisons of countries with and without a troop presence, simply because there are almost no countries without a U.S. presence, and instead look at the scale effect both cross-sectionally and over time.

\section{[INSERT FIGURE 1 HERE]}

In the following pages, we will show that the presence of those forces had a significant and robustly positive correlation with economic growth. On average, an increase in troop levels of an order of magnitude is associated with a 0.3 percent higher annual long-term growth rate of GDPP. Recognizing this finding is both new and controversial, much of the paper will present econometric evidence confirming its robustness.

Section 2 provides context in terms of the two relevant literatures, economic growth and international security. Section 3 presents the quantitative material, including 
data analysis, econometrics, and robustness tests. Section 4 is a theoretical discussion that considers causation, and why we do not believe reverse causation is likely to explain the troops-growth link. A final section concludes.

\section{LITERATURE REVIEW AND THE TROOPS HYPOTHESIS}

There exists a well-established assumption in the foreign policy community that security via military force, in principle, is a necessary condition for economic development. Surprisingly, there are no cross-country studies that attempt to empirically verify the point.

Excellent case studies and histories of post-war occupations of Japan and Germany exist (e.g. RAND's timely 2003 book by Dobbins et al.), as well as specialized research on specific aspects of post-conflict operations (Carafano 1997). However, neither simple correlations nor robust growth regressions have been estimated to try to define the general, cross-country troops-growth relationship. Even though the study of growth is a major discipline within economics, that literature has almost nothing to say about the effect of American troops.

Thus far, the literature linking military expenditures and national economic performance has focused on internal dynamics (e.g. British guns and British growth). Two channels have been postulated: the within-country relationship between defense spending and economic growth (usually found to be negative: inter alia, Heo (1998), Mintz and Stevenson (1995), and the surveys of Ram (1995) and Dunne, Smith, and Willenbockel (2005)), and the relationship between military conflict and economic growth (inter alia., Weede (1993), Murdoch and Sandler (2002), Reuveny and Thompson 
(2002)). These literatures leave completely unanswered the question of whether large numbers of country A's troops hosted by country B robustly predicts an improvement in B's economy.

One of the recurring themes of the recent growth research is the importance of good economic institutions. The historical research of Landes (1998), North (1990), Eric Jones (2003), and Weede (1996) concludes that good institutions are crucial drivers of long-term economic performance. Sala-i-Martin (1997a, b), Acemoglu, Johnson, and Robinson (2001), and Sala-i-Martin, Doppelhofer, and Miller (2004), have reached the same conclusion with quantitative methods: they generally find that successful economies have less corruption, stronger legal institutions, and lower levels of government consumption.

But how does a nation create good institutions? A political economy literature stretching back to at least Buchanan and Tullock (1962) and leading to the modern work reviewed in Drazen (2001) illustrates just how hard it is to create successful institutions. But how might foreign troops influence the process? Mancur Olson's theory in his Rise and Decline of Nations (1982) proposes the necessity of external shocks for breaking down the stagnant status quo of existing "distributional coalitions," and specifically lauds the transformative potential of foreign occupations. Indeed, Olson highlights the many post-war case studies involving U.S. troops, such as Germany and Japan, in contrast to postwar countries that saw fewer Americans as well as less development. His work pioneered the view that market failure could exist on the largest scale, and to an extent it defined the root cause of underdevelopment. Indeed, as the recent theoretical literature demonstrates, "barriers to riches" are often for sale to insiders who want to keep the 
status quo intact (Parente and Prescott 2001). And Paul Collier's The Bottom Billion (2007) summarizes his own research on poverty traps, concluding that "external military intervention has an important place in helping the societies of the bottom billion, and that these countries' own military forces are more often part of the problem than a substitute for external forces."

Motivated by the Olson-Collier conjectures, we hypothesize that a substantial portion of the troops-growth link reflects causation running from more troops to better economic performance. In our discussion below, we hypothesize that the troops-growth effect is likely to run through three main channels: the security umbrella provided by U.S. forces, diffusion of technology and institutions, and finally an aggregate demand stimulus from the U.S. forces. We discuss each briefly below.

Security Umbrella. Any military force will tend to provide a foundation of societal peace and stability in most circumstances, though clearly not all. Such peace is a necessary condition for economic activity to flourish - especially market forces which depend on the incentives of private property, in law and practice. At its heart, this is a simple articulation of the enforcement power underlying any effective rule of law. The armed force in this story need not be American military, or even military. It would, of course, be useful to examine the influence of other military forces (French, British, Soviet) in contrast to U.S. deployed forces, but that larger question requires data far beyond the capacity of this paper to address.

Diffusion. A second hypothesis we propose is that the long-term presence of American troops contribute positively to the diffusion of cutting-edge technologies and economic institutions. Discipline, lawful authority, respect for human and economic 
rights, construction standards - these are just a few of the most likely norms that are on display for any society with an accessible U.S. military base in its presence.

Aggregate Demand. A third hypothesis we propose is that a large deployment of U.S. troops involves a major demand stimulus to the local economy. This arguably contributes to the enhancement of market forces locally, but especially acts as a Keynesian boost to aggregate demand. Especially in a war-torn country recovering from all-out warfare (Japan, Germany, Korea), this story makes intuitive sense during the immediate post-war recovery period.

\section{MEASURING THE TROOPS-GROWTH LINK}

Countries with high U.S. troop presence during 1950-2000 enjoyed GDP per capita (GDPP) levels in 2000 nearly double the world average, while the 54 countries with the fewest U.S. troops had income levels that were roughly half the world average. Overall, the data indicate unambiguously that countries hosting large numbers of U.S. troops experienced faster economic growth than others. There are many possible explanations, but the empirical relationship alone is surprisingly strong.

Before turning to multivariate tests, a look at correlations and raw data should be useful. Table 1 below indicates that the presence of American troops had a positive correlation with both GDPP growth rates and GDPP levels, while Figure 2 below shows that countries with high levels of troops between 1950 and 2000 tended to have higher economic growth rates between 1960 and 2000. On average, high-troop-presence countries started rich and ended rich, relatively, but as our regressions models below 
demonstrate, poorer countries with few U.S. troops did not grow as quickly as similar neighbors that hosted more U.S. troops.

\section{[INSERT TABLE 1 HERE]}

[INSERT FIGURE 2 HERE]

Perhaps the most surprising fact is that the strong growth experience of highpresence countries is not limited to the three countries that most observers might immediately think of as "occupied” (e.g., Germany, Japan, and South Korea, all of which are in the top 10). In fact, countries that ranked $11^{\text {th }}$ through $20^{\text {th }}$ in terms of the number of American forces hosted (a group that includes Turkey, Greece, and Egypt) experienced GDP per capita growth of 2.82 percent and started wealthier (\$5603 in 1960), not poorer, than the top ten countries $(\$ 4916)$.

To give a sense of the magnitudes involved, we note that the top ten countries hosted 22.2 million U.S. troop-years during 1950-2000 - using “troop-year" to represent one soldier for one year, hereafter referred to simply as troops. In contrast, the second set of ten countries hosted one-twentieth of that amount: a total of 1.3 million troops during the same period. That is, the typical top ten country hosted 44,000 troops per year, while the typical second ten country hosted 2,600 troops per year. 


\section{Data}

To build a comparable explanatory variable for country-by-country deployment of U.S. troops, we use a new dataset from Kane (2004), which follows the Pentagon standard of counting a soldier stationed in-country for a single year during the September accounting exercise. Kane's U.S. troop deployment dataset includes 185 countries for each year during the period 1950-2003, and all but four of these countries hosted some number of U.S. troops greater than zero. Unfortunately, studying the impact of U.S. troops on economic growth was limited to the 94 countries with GDP data, starting in 1960 , which is the number of observations used in this paper. ${ }^{1}$ Naturally, this raises the question of sample bias in the study, but in fact the bias works against our theory, not in its favor. Many formerly communist countries, namely in Eastern Europe, could not be included; these were places with poor growth records and low U.S. troop presence. If all such countries could be included, it could only bolster the troops-growth correlation. In any case, 30 of the 94 countries examined here hosted less than 10 troops per year. And we further address the zero-troop situation by doing a decade-by-decade panel regression where 60 observations had zero troops.

\section{Econometric Tests}

Because this is the first study to consider the quantitative econometric impact of U.S. forces on economic growth abroad, we explore many possible treatments of U.S. troops which allows us to assess non-linearity. To illustrate, the most basic treatment is the sum of all deployment during 1950-2000. Recognizing that each additional troop may have diminishing returns to scale, we create a log-level measure for the entire 
period. We also created a sum of annual log-levels which would emphasize duration rather than an intensive short-term surge. ${ }^{2}$ Our primary goal is to see whether one or more of these troop measures have a robust relationship with long-term economic performance. We begin by reporting simple bivariate relationships between various measures of troop levels and measures of economic performance.

Table 2 reports the correlation coefficients of these troop variables; given our sample sizes, all are statistically significant at the 5\% level. LogTroops, the base 10 $\operatorname{logarithm}^{3}$ of the total number of U.S. troops in a country during 1950-2000, had very strong statistical relationships with GDP per capita measures for 94 countries, both the average annual growth rate over 1960-2000 (r=0.486) and year 2000 log level $(r=0.615)$. Figure 2 shows the LogTroops-growth relationship in a scatterplot.

\section{[INSERT TABLE 2 HERE]}

Other troops variables considered include troops per capita, LogTroops per capita, Presence (a measure that emphasizes duration by summing up annual log troop levels), and two threshold measures. The first threshold measure (Years100) is a count of how many years the number of troops exceeded 100 in a given country, while the second (Years1000) counts the years with a thousand or more troops.

To further assess the relationship's economic and statistical significance, we run a set of multivariate ordinary least squares (OLS) regressions that include three commonly used variables in the growth literature. In order to rule out omitted variables bias, we also 
run a series of regressions using many other variables found to be significant for economic growth (Sala-i-Martin 1997a, b) as well as measures of foreign aid.

The three control variables are used in all regressions are log GDP per capita in 1960 and two measures of 1960 human capital: primary school enrollments and life expectancy. The human capital measures typically have positive regression signs. The initial level of GDPP tends to have a negative sign in growth regressions because of conditional convergence. When the three variables are included in a model with no other explanatory variables, they explain 47 percent of growth variation $\left(R^{2}=.471\right)$. Results for this regression and others that introduce the different troop variables are reported in Table 3. Including LogTroops in the regression raises $R^{2}$ to 0.540 , with LogTroops significant at the one percent level (a t-statistic of 3.63) and a coefficient of 0.346. Thus by including LogTroops, an additional 7 percent of growth variation is explained.

As for economic significance, the basic regression (Table 3, column III) implies that a tenfold increase in troop levels in the typical country is associated with a one-third percentage point higher long-term growth rate of per capita gross domestic product (GDP) per year in that country during 1950-2000. This would imply that if a country went from hosting no U.S. soldiers to hosting 100,000 soldiers per year for a decadegoing from essentially no troops to the level of troops the U.S. currently has in Germany - that country would be predicted to grow an average of 1.8 percent faster per year.

[INSERT TABLE 3 HERE]

[INSERT FIGURE 3 HERE] 
Figure 3 shows the relationship between the fitted values of GDP growth (controlling for starting GDP, education, and life expectancy) and LogTroops. The Yvalues are therefore the residuals from the basic regression, excluding the fitted values for LogTroops; the partial $\mathrm{R}^{2}$ between LogTroops and the fitted values is 42 percent.

Other troop variables that retain significant explanatory power alongside common explanatory variables are Presence, LogTroops per capita, and both troop threshold counts (Years100 and Years1000).

The resulting $R^{2}$ for the Presence model is 0.523 , with a t-statistic of 3.15 and a coefficient of 0.007 . A single year with 10,000 U.S. troops in country $i$ increases the Presence measure for that country by 4 , resulting in an average increase of 0.028 percent economic growth for every year over many decades. This coefficient is difficult to interpret, but an example may help. France and the Philippines hosted similar numbers of American troops during the latter $20^{\text {th }}$ century, just under 700,000 each. Thus, the values of LogTroops stationed in France and the Philippines during 1950-2000 are nearly identical, 5.84 and 5.83 respectively, but their Presence values are wide apart, 142.4 and 194.2, because U.S. troops were in France for a shorter duration. The positive coefficient for Presence implies that the Philippines benefited more from the same number of U.S. troops than France.

Coefficients on the threshold measures are easier to interpret: one extra year with more than 100 soldiers adds 0.02 percentage points to growth every year $(t=2.92) .{ }^{4}$ So, for example, a country that has 100 U.S. troops hosted for 15 years would be predicted to grow an extra 0.30 points per year during 1960-2000. 
Two measures that do not have explanatory power are instructive (the raw count of Troops and Troops per capita) because many researchers who explore the effect of troops on foreign countries are likely to consider the linear treatment (Troops) in some fashion and stop there. The results shown in Table 3 reveal distinct scale and threshold effects of troops.

\section{Robustness of the Result}

To determine which troop measure (if any) has a robust relationship with economic performance, one needs to rule out many other possible explanations. This section addresses numerous alternate explanations for growth, including things that might be simultaneously be driving troop deployment and economic growth. This section looks at (a) other explanatory variables, including conventional growth regressors as well as U.S. military and economic aid, (b) outliers in the data (namely high-growth countries with high U.S. troop presence, such as Japan, Germany, and South Korea) and (c) nonlinearities and interaction effects.

First, we consider dozens of the most commonly cited variables that have been found to correlate strongly with international growth rates, and use the Leamer (1983) extreme bounds test. Leamer's recommended approach to testing new explanatory variables is to run a wide variety of regressions using plausible control variables; if the new explanatory variable is statistically significant at conventional levels in all regressions, then the new variable is tentatively considered "robust." Sala-i-Martin (1997a,b) considers this test too strong as a general rule, ${ }^{5}$ however, our goal is to raise a high bar for introducing new growth variables into the literature. 
Accordingly, we run 21 regressions for each troop measure. A troop measure passes our extreme bounds test if it is statistically significant at the $5 \%$ level in all 21 regressions. Each regression includes five variables: one troop measure, the three "fixed" control variables (employed in Sala-i-Martin $(1997 \mathrm{a}, \mathrm{b}))$ which are primary schooling in 1960, life expectancy in 1960, and $1960 \log$ GDP per capita, and one of the 21 variables that passed the robustness test of Sala-i-Martin $(1997 a, b) .{ }^{6}$ These 21 variables include measures of war, revolutions and coups, rule of law, openness to trade.

Two of our troop measures pass the extreme bounds test: LogTroops (1950-2000) and LogTroops 1950s. All others failed the extreme bounds test, though it should be noted that the coefficients were always positive for every troop measure we considered. In the spirit of DeLong and Lang (1992), we note that it is extremely unlikely that we would find coefficients that are always positive if they came out of a data generating process where the true parameters were in fact negative or zero. As DeLong and Lang's work implies, this is true regardless of the size of the estimated standard errors. To run hundreds of regressions and never find a negative coefficient provides strong evidence that the underlying data generating process exhibits a positive correlation between troop levels - however measured — and economic performance.

[INSERT TABLE 4 HERE]

Some of the most interesting regression models we used in our robustness tests of LogTroops are presented in Table 4. We present models with variables for economic policy, conflict, regional dummies, socio-political factors, and foreign aid from the U.S. 
Including orthodox variables that are well-known for their positive impact on growth in recent decades had no impact on the significance of LogTroops for growth. The variables considered include equipment investment, trade openness, absolute latitude, and religious demography. Each of these add explanatory power to our linear regressions, but none of them substantially diminishes the economic or statistical significance of LogTroops. The conventional capital measure (equipment investment) is shown to be statistically insignificant (Table 4, column I). Trade openness is the one policy variable (other than rule of law) that is statistically significant in our regressions. However, like rule of law, it is less economically significant than LogTroops: The standard deviation of openness (measured in fraction of years open to trade) is 0.34 , so a standard deviation increase in openness raises predicted growth by $0.44 \%$ per year. Thus, if we are willing to think of LogTroops as a policy variable, it is the most economically and statistically significant of the policy variables we consider here.

Regional dummy variables matter here because U.S. troops were heavily concentrated in East Asia and Western Europe in the decades after World War Two, but essentially zero in Africa. The sub-Saharan Africa (SSA) dummy proves borderline statistically insignificant in the model $(\mathrm{t}=-1.73)$ and has no impact on LogTroops $(\mathrm{t}=$ 2.51). In other words, it is not just the lack of American forces in Africa that generates the significant and positive correlation of troops with growth. We also utilize Sala-iMartin's WAR dummy, which is of particular interest for this analysis. The correlation is zero $(\mathrm{R}=0.002)$ between WARDUM and LogTroops, but including it allows us to isolate a qualitative distinction between the type of troop engagement in different countries. The inclusion of the war dummy barely raises the adjusted $R^{2}$ to .548 , and 
leaves the dummy itself insignificant at the $10 \%$ level. ${ }^{7}$ Likewise, the variable for Revolutions and Coups is insignificant.

We next consider a handful of variables associated with political stability, including measures of civil liberties, revolutions and coups, political rights, and even a measure of democracy. Only one of these variables, rule of law, is statistically significant at the $10 \%$ level when included in our regressions, and none diminish the statistical or economic significance of LogTroops, and so results are not reported in the Table 4 except for the democracy measures. Given that all of these variables have already passed Sala-i-Martin's (1997) robustness test, their inability to lower the statistical significance of troops below the $1 \%$ level is all the more impressive. The coefficient on LogTroops also remains quite stable - between 0.345 and 0.383 - in regressions that include a socio-political variable. The one exception is when "Democracy1965" is included, which raises the LogTroops coefficient to 0.454 and raises the adjusted $R^{2}$ to 0.602 .

Adding too many controls at once could give unreliable estimates-for this reason, growth regressions typically have no more than $6-8$ controls-but to give a sense of how LogTroops performs in a bigger regression, we ran a final test for the hypothesis that troop deployments might be a mere proxy for local institutions and geography: We regressed growth on our three standard controls, plus LogTroops, sub-Saharan Africa and other regional dummies, and six more institutional and political controls: war, revolution, instability, civil and political liberties, and democracy. To save space, we refrain from reporting full results, but we note that even here, the LogTroops coefficient was littlechanged: $0.33 \%$, with a standard error of $0.14 \%$. The only other statistically significant 
controls were primary schooling (positive) and starting GDPP and the war dummy, both negative. In the data at our disposal, LogTroops does not appear to be a mere proxy for some other institutional characteristic of the host country.

\section{American Intentions and Foreign Aid}

Shifting attention from well-known variables in the growth literature, we next turn to an alternative explanation that springs forth from scholarship on international affairs. Perhaps LogTroops are simply a proxy for the U.S. engagement more broadly. While appealing, such things as diplomatic engagement are arguably impossible to measure. Yet there are clear cut variables we can examine, such as foreign aid. It is an article of faith that the Marshall Plan was instrumental in rebuilding the economies of Western Europe in the years following World War II, when $\$ 53$ billion in military aid and $\$ 91$ billion in economic aid (in 2003 dollars) were given by the U.S. in grants and loans to countries in the region during the years 1949-52.

Realist and liberal traditions would both explain U.S. involvement in Western Europe as motivated by anti-communism. Indeed, many argue that the expansive postwar economic arrangements for currency (Bretton-Woods) and trade were designed largely to strengthen allied economies partly as a defensive structure aligned against the Soviet Union. These perspectives would hold that the presence of American soldiers was secondary—at best—in spurring economic growth.

To test this conventional hypothesis, we consider variables for aid from the United States to other countries after World War II: real military aid and economic aid, and logs of both (USAID Greenbook 2008). ${ }^{8}$ Our variables include aid during the years 
of the Marshall Plan, the Mutual Security Act (1953-61), and all other aid programs up to 2000. The amount of U.S. economic aid directed to our sample of 94 countries during 1949-2000 sums to $\$ 514$ billion, while total military aid totals $\$ 365$ billion.

\section{[INSERT TABLE 5 HERE]}

As we can see in table 5, the correlation between troop measures and aid is solid, but only strong with $\log$ Military Aid. In growth regressions, however, no measure of foreign aid is statistically significant nor adds any explanatory value to the growth rates

of foreign countries (see Table 4, column VII and VIII). The inclusion of log Military Aid actually weakens adjusted $R^{2}$.

\section{Outliers and nonlinearities}

The number of American troops deployed to three countries during the Cold War era dwarf all others. A total of 10,452,416 troops were based in Germany from 19502000. In Japan, the number of troops was 3.94 million, while the number for South Korea was 3.34 million. Combined, these deployments account for three-quarters of the troops based in countries included in this study, and more than half of the global total of 27.3 million. Since these three economies have been relatively successful in the postwar era, one might reasonably wonder if they are driving the results. Thus, we rerun our benchmark regressions which exclude these outliers. But before doing so, we should note that the mere fact that log measures of troops were more robust than level measures is itself evidence that these outliers are not driving the results. 
With this caveat in mind, we turn to a re-estimation of some key results from Table 3, reported in Table 6. We rerun the specifications for LogTroops from 19502000, LogTroops from 1950-59, and LogTroops from 1960-1969. All three remain significant at conventional levels. The impact of a tenfold increase in U.S. troops on a country's average annual growth rate is +0.281 percentage points with this sample, down slightly from +0.346 for all 94 countries.

\section{[INSERT TABLE 6 HERE]}

Another interesting possibility is multiplicative interactions between LogTroops and other conventional growth variables. A Ramsey RESET test indicated that nonlinearities were likely to be statistically significant, so we ran a separate nonlinear specification that included interaction terms between LogTroops and all of the variables

included in Table 3, and also included the square of LogTroops. ${ }^{9}$ Of these additional variables, only the interaction between LogTroops and 1960 log GDP per capita was significant at the 5\% level with a negative sign (a result we explore below), while the quadratic LogTroops term was positive and significant at the $10 \%$ level. The same nonlinear results hold if $\log 1950$ 's or $\log 1960$ 's troop estimates are used instead; in all three cases, troop coefficients remain statistically significant, but substantial interaction effects exist.

[INSERT TABLE 7 HERE] 
Let us interpret these results with one typical specification and a simple simulation, both reported in Table 7. The results imply that the troops-growth relationship is much stronger in poorer countries. The cross-partial derivative implies that the troopsgrowth coefficient falls by $0.27 \%$ per year for every log-point increase in the country's starting GDP per capita. U.S. troop presence predicts strong future growth in the poorest countries, and weak or even negative growth in the richest countries.

The negative cross-partial is consistent with a story that U.S. troops transfer bestpractice institutions and technology to poorer countries; after all, there is more room for institutional and technological convergence when countries begin with weak institutions and little technological expertise. It fits in less well with a security umbrella story, since that effect might reasonably be constant (in log or percentage terms) across countries.

\section{Panel Data Analysis}

Next we perform a panel data analysis with time and country fixed effects. In addition to multiplying the total number of observations from 94 to 302, panel estimates include many observations with zero U.S. troops. This approach introduces the additional difficulty of getting reliable, decade-level data on country-specific control variables (not for troops or for growth). With that caveat in mind, we ran panel estimates as a robustness check of our previous results. We regressed each period's GDPP growth rates on the log troop levels of the preceding decade.

Table 8 looks at (four) one-decade and (two) two-decade growth periods, and includes both time and country fixed-effect dummies. The country fixed-effect country dummy absorbs any country-specific persistent trait: institutional history, geography, 
disease susceptibility, or culture, while the time dummy absorbs any global economic trends during the relevant period. In both approaches, we included two readily-available time-varying controls: primary schooling at the start of period (from Barro and Lee (1993) and starting log GDPP.

Table 8 shows that LogTroops are statistically significant at the $1 \%$ level. In both the one- and two-decade panels, the estimated coefficient is stable around 0.5 , a value which can be interpreted as follows: increasing hosted troops in a typical country by one order of magnitude during a decade is associated with higher annual economic growth rates by one-half a percentage point during the following decade. Overall, our results indicate that high levels of U.S. troops in a given country in the current decade predict faster economic growth ten to twenty years in the future.

[INSERT TABLE 8 HERE]

[INSERT TABLE 9 HERE]

\section{WHY IS THERE A TROOPS-GROWTH LINK?}

The troops-growth relationship is clearly no artifact of our estimation procedure, given that two measures - LogTroops and LogTroops 1950s — pass Leamer's extreme bounds test, and are robust to panel estimation with time and country fixed effects. Now we turn our attention to explaining what might be causing this robust relationship. To our knowledge, there is no formal empirical evidence showing whether or how foreign troop deployments correlate with or influence long-term economic performance. 
The conventional assumption is that foreign troops can enhance national income in host countries, especially if deployed in large numbers and if involving permanent base/infrastructure. This is an argument that draws on the Keynesian story whereby domestic government consumption can boost aggregate demand. The idea is also similar to the literature on domestic defense expenditures being good for gross domestic product. We call this the Expenditure Theory.

Mansur Olson argued in favor of the potential stabilizing disruption of an occupation. Olson's theory offers few tangible mechanisms, but can be understood in terms of foreign troops as agents of change that diffuse productivity-enhancing technology and institutions. A refinement of this second idea would be that U.S. troop presence is a proxy for a strong commitment to institutional reform by the U.S. government. We call this the Diffusion Theory, and it is close to a consensus among modern growth economists about how long-term development happens.

Paul Collier focuses on the capacity for military interventions (specifically in failed states, but we will generalize) to suppress inter- and intra-state violence. The four roles he describes include "expelling aggressors" as well as "restoration of order, maintaining post-conflict peace, and preventing coups. Collier's vision is a sub-set of what we call the Security Theory. He does not imagine a longer-term alliance intervention along the lines of essentially permanent bases in Japan, or NATO countries like France and Britain for that matter. But few would argue that peace is a necessary condition for growth. 
In addition to considering these causal mechanisms, we will also consider the possibility of reverse causality - the hypothesis that U.S. troops are generally deployed to countries that are growing quickly and likely to continue.

The performance of different troop measures can help inform which of three theories, if any, have merit. The expenditure effect should work linearly, that is, without decreasing returns to troops. Reviewing Table 2, raw (non-logged) treatments of any troop measure has a weaker relationship with economic growth than the alternative measures. Table 3 confirms that raw troop measures were not robust econometrically, nor is the Troops per capita measure. The significance of logged alternatives suggests that the impact of troops have diminishing returns to scale on host country growth. Consequently, Expenditure Theory does not seem to have empirical support.

Additionally, the log of troops per capita proved fragile. The implication is that the size of the host country population is not very important. More troops, even more troops per capita, are not proportionally more exposed to the host society. Ruling elites and the media are likely to have high levels of exposure to American troops, regardless of the country size.

The Presence measure - which is larger for longer-duration deployments captures the diminishing returns to scale effect as well, but implies a potentially vital aspect of the troops-growth relationship. The duration of an active military deployment is possibly more influential towards economic growth than the number of troops.

\section{Troops as security umbrella}


Stability and security are the normal objectives for U.S. forces deployed overseas. The strategic mission in the Cold War was to preserve "peace through strength," and that favored large permanent deployments in key locations: The presence of over ten million troop-years in Germany from 1950-2000 is a prime example.

The "security umbrella" that U.S. troop deployments generally provide is a key mechanism through which American soldiers could enhance the growth potential of an economy. Domestic actors are more likely to defer consumption in favor of investment when the probability of payoff rises, which is a probability closely tied to the peace and security of area.

Further, the security guarantee of U.S. troops is a powerful signal to foreign investors, perhaps even a deciding factor for multinational firms deciding where to install new capital equipment and where to bring their technology-diffusing organizational capital. American-guaranteed security would tend to spur higher levels of both domestic and foreign direct investment and would lower the risk premium in interest rates. Finally, the presence of American security forces allows a host nation to lower its own defense expenditures, which can be a sizeable savings. This tends to reduce government consumption, which allows the country to use more of its own resources for physical and human capital accumulation. The security umbrella effect therefore encompasses multiple channels, all of which imply a rise in investment in both physical and human capital.

Empirical support for this mechanism was recently provided by Biglaiser and DeRouen (2007), who also used Kane (2004) data and concluded, "[the] novel result is 
the positive effect of US troops in attracting US capital inflows." Interestingly, they found a higher FDI inflow from U.S. firms, but not other nations' firms.

\section{Diffusion of Institutions}

Most U.S. occupations involve explicit efforts by the U.S. government to create long-lasting institutions such as the recognition of stable currencies and financial systems and the rule of law; such interventions would be likely to raise a country's steady-state living standards, and hence, its growth rate as measured by typical growth regressions.

However, many U.S. occupations also involve explicit efforts to encourage democracy, notably the introduction of democracy in post-war Japan, and ongoing efforts throughout the Middle East. This creates some ambiguity in the expected sign of the troops-growth relationship, since democracy's impact on growth is ambiguous (inter alia, Barro and Sala-i-Martin, 2004). Therefore, only empirical estimation can reveal the nature of the troops-growth relationship.

How might U.S. troops directly change a nation's institutions? In recent years, all one needs to do is read the newspaper to see the size and scope of the U.S. military's involvement in institutional change: Whether in Kosovo, Afghanistan, or Iraq, U.S. troops are intimately involved in meeting with local leaders, helping to arrange elections, training police forces, resolving local disputes, and, generally participating in the civic life of these countries. Of course, smaller deployments would have fewer interactions with local citizens, but since such interactions are often likely to be with leading political and military figures, they may still have large institutional effects. 
As a general rule, whether intended or not, the presence of U.S. troops involves cross-cultural exposure, and that means the U.S. standards of law, property, human rights, and respect for human dignity are inevitably on display. Diminishing returns of troops also suggests that the key institutional effects are centralized. To the extent troops affect faster diffusion of innovations, they may play more of an exemplary role, not a direct change agent role per se.

These institutional changes need not be intentional; for example, if a local firm wants to have a long-term contract to provide laundry or food services to the U.S. military, that firm will find that it needs to learn U.S. accounting conventions simply to remain eligible for the contract. And as it learns such accounting conventions, the firm's own institutions will thereby change.

\section{Troops as an objective measure of institutional change}

When U.S. troops arrive, they are backed by the efforts of many other branches of the U.S. government. Therefore, troop levels may be a good proxy for all efforts at institutional change, whether implemented by the State Department, the Commerce Department, the Office of the Trade Representative, or other agencies. The quantitative measure of troop levels is the measurable element of this package of institutional interactions between the U.S. and the host countries.

Incorporation of specific institutional parameters into growth research has increased significantly in the last few years (inter alia, Acemoglu, Johnson, Robinson (2004), and many articles in Aghion and Durlauf (2005)). Economists use a wide variety of proxies for such institutional variables. Sala-i-Martin $(1997,2004)$ for example, uses 
measures on "degree of capitalism," "political rights," and "rule of law" as measures of institutional quality. These measures have strengths (working well in growth regressions) and weaknesses (assembled through non-transparent methods such as surveys of business owners and judgment calls by scholars). The possibility for contamination of such measures is clear: Survey respondents may be likely to consider a rich country to have "good economic institutions" simply because businesses are successful there, and scholars may be likely to judge a country as "strongly capitalistic" if the economy is highly productive.

Therefore, it would be useful to have a reliable, quantitative measure of at least one form of institutional quality. Troop deployments by the United States, the world's leading economy, may prove to be the kind of non-subjective, quantitative measure of institutions that growth economists have long looked for (cf. Acemoglu et al, 2001, for another index of institutional change).

\section{Reverse causality?}

Establishing a close relationship between American troop deployments and national growth rates leaves open the question of whether troops cause growth or vice versa. Regarding this potential endogeneity, it may be helpful to think of the supply of and demand for troops separately.

It seems unlikely that U.S. military policymakers explicitly chose to send (supply) troops to countries with high expected growth. We can think of three reasons to rule out this story, which we discuss at greater length below. First, accurate growth expectations were all but unknowable to observers at the time - the experts were on the wrong side of 
history during our time period. Second, it is the nature of military engagement to put troops in harm's way, i.e. in places of maximum instability and therefore inhospitable to economic investment and growth. Third, the historical record does not support this kind rationale among America's leadership.

On the first point, the fact that economic growth remains an intensely active field of research even today is because the root causes of growth remain in dispute, partly because "ultimate" causes such as institutions and culture resist quantitative assessment. Regarding proximate factors that can be measured, we must acknowledge that the workhorse models of economic growth were only developed in the late 1950s (e.g. Solow 1956) and 1990s (e.g. Romer, 1990), but even these are famous for leaving the vast majority of growth causes as an unexplained residual. In hindsight, the recovery and sustained growth of Western Europe appears obvious, but it was anything but obvious in 1945 when the continent lay in rubble, populations were decimated, and communist Russia loomed ominously. If one were to predict which regions of the world had the highest growth potential after World War Two, Africa and Latin America would top the list (Maddison 1994). Growth in Africa was widely expected to take off after colonial rule ended (Bloom and Sachs, 1998; Easterly 2002) ${ }^{10}$. China and southern Asia were the poorest, most backward regions, with limited natural resources and expected to continue as such.

Despite Africa's post-colonial promise, and despite the aid dollars that went to Africa during the late $20^{\text {th }}$ century, U.S. troop engagement was all but nil. Deployments were ten times higher to Latin America and the Middle East, and hundreds of times higher to Asia and Europe. 
In hindsight, it could be that the Pentagon turned out to be an excellent venture capitalist organization, with foresight beyond that of most economists of the day. But is there any record of an American president deploying troops based on the growth potential of the destination? Was Korea, Vietnam, Kuwait, or Somalia selected for military engagement (in public or private comments) for growth? Even if one focuses on the importance of Middle East oil to the global economy, that is a rationale based on ex-ante resources as a basis for deployments, not a story about expected growth.

The contrary thesis seems closer to the truth, namely that troops are deployed to unstable areas with presumably lower growth potential. This holds for the U.S. wars in Vietnam in the 1960s, the Balkans in the 1990s, and certainly Afghanistan today. Other countries have followed the same path, with well-known foreign deployments to unstable areas, namely the French involvement in Vietnam and Algeria, the Soviets in Afghanistan, Cuba, and Nicaragua, and the Chinese in Korea and Tibet. These were not missions to ex-ante promising regions.

Many if not most troop deployments are specifically implemented in order to create stability in places that are contemporaneously unstable - they only become stable after years of American troop presence. Note that we have tested for the effect of strife by including in our growth regressions dummies for wars as well as revolutions/coups, and even regional dummies that net out low-growth, high-conflict regions. As noted, the strong relationship between troops and growth persists when these dummies are included.

Another possibility is that the presence of U.S. troops in a country is simply an indicator of past wars and past destruction of physical capital. If massive amounts of physical capital have recently been destroyed through war and civil strife, then in a 
canonical Solow/Ramsey-style growth model, there is a large opportunity for rapid catchup growth, as the war-ravaged country quickly rebuilds and converges to its old, pre-war steady-state growth path. Thus, a past war could cause troop deployments and hence rapid future growth. Again, we have attempted to control for this by using starting-period GDP per capita as a proxy for the pre-existing level of tangible and intangible capital. Since troops are robustly associated with growth even when conditioned on beginning-ofperiod GDP per capita, we conclude that the simple war-repair mechanism is an unlikely explanation of the troops-growth relationship.

Finally, the historical record does not seem to support the idea of reverse causality. Korea is the most telling example of how the story fails. South Korea today stands as a singular example of "miraculous" economic growth. Yet in 1949, the peninsula was not widely valued economically by the U.S., China, or the Soviet Union. According to historian, Max Hastings (1987), "The Pentagon had anyway adopted a consistent view that Korea was of no long-term strategic interest to the United States." Engagement there after defeat of Japan in late 1945 by dividing the peninsula at the $38^{\text {th }}$ parallel was driven solely by the nascent strategy of containing the spread of Soviet influence (Hastings 1987, McCullough 1992). It must be recalled that the northern half of the country was considered far richer and, in the word of the day, industrialized. In January of 1950, Secretary of State Dean Acheson famously left Korea out of a perimeter of countries where the U.S. had interests (that this contributed to the invasion has been debunked). By the time of the North's invasion in June of 1950, the U.S. had completely withdrawn its last forces from the peninsula. The fact is that troops were not deployed to 
Korea for economic reasons, not in 1950 and not since. The case for troop deployments to high-wealth countries is weak enough, but the case for high-growth is even weaker.

Supply-side endogeneity requires believing that U.S. Presidents and other military policymakers are targeting troop deployments to countries with high expected economic growth. Based on our strong results even when controlling for these supply-related factors, we tentatively conclude that on the supply side an important role for endogeneity is unlikely.

\section{Demand for Troops?}

The demand by foreign countries for American troops seems unlikely as an explanation for reverse causality for many of the reasons outlined above, particularly the unknowable nature of growth as well as instability rather than stability as a demand driver. Yet there may be some endogenous logic to the demand for troops to stay after they have arrived.

Consider two allied countries with a heavy U.S. presence. The country experiencing fast growth may be more willing to allow the continued stationing of American troops there, while a country with a weakening economy may experience domestic pressure to scapegoat and expel American forces. An example of this story is the Philippines, home to the first and second largest overseas U.S. military installations in the world for many decades (U.S. Naval Base Subic Bay and Clark Airbase). In 1960, the country had a GDPP that was 35 percent larger than South Koreas which in 1990 was 70 percent lower. In 1991 the Philippine legislature refused to renew agreements that would allow it to continue hosting American military forces, and by 1993, only 53 
American troops remained stationed there. Where this story fails is the reverse: countries that grow or recover from conflict more quickly might wish to be independent of a foreign military presence. France grew rapidly in the decade before expelling the U.S. military in the mid 1960s, while Thailand's economy also expanded rapidly before the U.S. left in the 1970s. Also, one could argue that slow relative growth in Spain, Italy, Portugal, and especially Germany have not led to a policy shift in support for maintaining a large U.S. presence.

While deserving more study, the link between economic growth and both the supply and demand for U.S. troops is ambiguous. Fully modeling the domestic political climate that would generate this demand for troops is beyond the scope of this paper. We hope that the robust results we present above encourage other researchers to explore the theoretical and empirical links between troop deployments and economic growth.

\section{CONCLUSION}

We have shown in this paper that the presence of American troops typically led to

higher economic growth in host countries during the second half of the $20^{\text {th }}$ century. This troops-growth relationship has not previously been established, and various robustness tests showed the effect to be stable across multiple specifications, using cross-country and panel regressions, and even when dropping outliers.

We considered three theories that might have driven the troops-growth relationship - Expenditure, Diffusion, and Security. Data analysis does not support the notion that Keynesian expenditures from a larger troop presence stimulate host-country GDP - the effects are too long-lasting for demand-side explanations. The importance of 
security, articulated recently by Paul Collier, appears to fit our data well (and hints that duration of commitment matters as much as force strength). Lastly, the theory that foreign forces act as institutional change agents, proposed by Mancur Olson decades ago, is supported by the robust strength of logged troop variables in our econometric tests. In light of the link established here with macro data, discovering the mechanism behind the troops-growth relationship is an interesting question for future research.

Empirically, models that included U.S. troop variables confirmed their statistical and economic significance at remarkably high levels. Importantly, the significance of LogTroops proved robust in the most extreme circumstances, with a stable coefficient that implies the ten-year basing of 10,000 American soldiers in an average country boosted growth rates there by 1.5 percent or more annually for a half century (that is, an additional 0.3 percent for each tenfold troop increase). To be sure, absolute troop levels matter for growth, but with decreasing returns.

The presence of U.S. military troops is surely related to a wider American commitment, one that involves foreign aid, diplomacy, trade, investment, and a host of other factors. The fact that U.S. troops are much simpler to quantify, and that other factors such as diplomatic and technology diffusion are quite impossible to quantify, means that troop variables are likely serving as a useful proxy for this wider commitment. But if the underlying, unmeasured relationship between U.S. troops and U.S. political commitment remains robust, then our results likewise remain robust. However, we did confirm that troops are better predictors of future growth than economic or military aid. The implications of competing theories of international relations are not as clear cut as they may seem. A simple reading of the troops-growth link would seem to bolster 
the idealist view of the normative value of expansive U.S. engagement. Likewise, the results could be read as a validation of hegemonic stability theory. However, it would be a mistake to read this paper's message as a call for military deployments to nations where policymakers want to boost growth, for no other reason than that most deployments described here evolved slowly and with mutual consent. We are skeptical that the effect will or possibly can occur in an environment where American forces are unwelcome.

We hope that these macro-level results encourage others to look more closely at the micro-level institutional mechanisms whereby a U.S. troop presence can improve long-run economic performance. Is total factor productivity higher for firms located near U.S. military bases? How do political institutions change in the presence of the U.S. military? Are trade and foreign investment growth notably faster following the deployment of American soldiers (For affirmative answers, see Biglaiser and DeRouen 2007)? By discovering the key micro-level channels driving the troops-growth relationship, future work can better explain the positive relationship between military deployments and the wealth of nations. 


\section{REFERENCES}

Acemoglu, D, S. Johnson and J. Robinson. 2004. Institutions as the Fundamental Causes of Long-Run Growth. NBER Paper w10481, May 2004.

Acemoglu, D., S. Johnson and J. Robinson. 2001. The Colonial Origins of Comparative Development: An Empirical Investigation. American Economic Review, December, 2001, volume 91, pp. 1369-1401.

Aghion , Philippe \& Steven Durlauf (ed.). 2005. Handbook of Economic Growth, $1^{\text {st }}$ ed., Amsterdam: Elsevier.

Barro, R. J. and Lee, W. 1993. International Comparisons of Educational Attainment. Journal of Monetary Economics, 32, 363-394. Data available at www.nber.org.

Barro, R. J. and Sala-i-Martin, X. 1992. Convergence. Journal of Political Economy, 1002, 223-251.

Barro, Robert and Xavier Sala-i-Martin. 2004. Economic Growth, 2nd ed., Cambridge, MA: MIT Press, page 522.

Biglaiser, Glen and Karl DeRouen, Jr. 2009. Interdependence of U.S. Troop

Deployments and Trade in the Developing World. Foreign Policy Analysis 5, 247-263.

Biglaiser, Glen and Karl DeRouen, Jr. 2007. Following the Flag: Troop Deployment and U.S. Foreign Direct Investment. International Studies Quarterly 51, 835-854.

Bloom, David E. and Jeffrey D. Sachs. 1998. Geography, Demography, and Economic Growth in Africa. Brookings Papers on Economic Activity, 2: 1998.

Buchanan, James M. and Gordon Tullock. 1962. The Calculus of Consent: Logical Foundations of Constitutional Democracy Ann Arbor: University of Michigan Press, 1962.

Carafano, James J. 1997. Swords into Plowshares: Postconflict Arms Management. Military Review, Vol. LXXVII, No. 6, November-December 1997.

Collier, Paul. 2007. The Bottom Billion: Why the Poorest Countries are Failing and What Can Be Done About It. Oxford University Press, 2007

DeLong, J. Bradford and Kevin Lang. 1992. Are All Economic Hypotheses False? Journal of Political Economy 100:6 December, pp. 1257-72.

Dobbins, James, John G. McGinn, Keith Crane, Seth G. Jones, Rollie Lal, Andrew Rathmell, Rachel Swanger, and Anga Timilsina 2003, America's Role in NationBuilding: From Germany to Iraq, RAND. 
Drazen, Allan. 2001. Political Economy in Macroeconomics, Princeton, NJ: Princeton University Press.

Dunne, J. Paul, Ron P. Smith, and Dirk Willenbockel. 2005. Models of Military Expenditure and Growth: A Critical Review. Defence and Peace Economics, 16:6Dec: 449-461.

Easterly, William. 2002. The Elusive Quest for Growth. Cambridge, Massachusetts: The MIT Press.

Hastings, Max. 1987. The Korean War. New York: Simon \& Schuster.

Heo, Uk. 1998. Modeling the Defense-Growth Relationship around the Globe. Journal of Conflict Resolution, 42 Oct: 637 - 657.

Heston, Alan, Robert Summers and Bettina Aten. 2002. Penn World Table Version 6.1, Center for International Comparisons at the University of Pennsylvania (CICUP).

Hoover, Kevin D. \& Stephen J. Perez. 2004. Truth and Robustness in Cross-country Growth Regressions. Oxford Bulletin of Economics and Statistics, Blackwell Publishing, vol. 665, pages 765-798.

Jones, Charles. 2002. Introduction to Economic Growth. New York, NY: W.W. Norton.

Jones, Eric. 2003. The European Miracle: Environments, Economies and Geopolitics in the History of Europe and Asia. New York: Cambridge University Press, 3rd ed.

Jones, Garett and J. Schneider. 2006. Intelligence, Human Capital, and Economic Growth: A Bayesian Averaging of Classical Estimates BACE Approach. Journal of Economic Growth, 11:71-93.

Kane, Tim. 2004. Global U.S. Troop Deployment, 1950-2003, Center for Data Analysis Report 04-11, The Heritage Foundation, October 27, 2004.

Landes, David. 1998. The Wealth and Poverty of Nations: Why Some Are So Rich and Others So Poor. New York: W.W. Norton.

Leamer, Edward. E. 1983. Let's Take the Con Out of Econometrics. American Economic Review, 73, 31-43.

Levine, R. \& Renelt, D. 1992. A sensitivity analysis of cross-country growth regressions. American Economic Review, 82, 942-963.

Maddison, Angus. 1994. Explaining the Economic Performance of Nations, 1820-1989 in Convergence of Productivity, William J. Baumol, Richard R. Nelson, and Edward N. Wolff, eds. New York: Oxford University Press. pps. 20-61. 
Mankiw, N. G., Romer, D. \& Weil, D. 1992. A Contribution to the Empirics of Economic Growth. Quarterly Journal of Economics, 107, 407-38.

McCullough, David. 1992. Truman. New York: Simon \& Schuster.

Mintz, Alex and Randolph T. Stevenson. 1995. Defense Expenditures, Economic Growth, and the 'Peace Dividend': A Longitudinal Analysis of 103 Countries. Journal of Conflict Resolution, 39Jun: 283 - 305.

Murdoch, James C. and Todd Sandler. 2002. Economic Growth, Civil Wars, and Spatial Spillovers. Journal of Conflict Resolution, 46 Feb: 91 - 110.

North, Douglass C. 1990. Institutions, Institutional Change, and Economic Performance. New York: Cambridge University Press.

Olson, Mancur. 1982. The Rise and Decline of Nations, New Haven, Conn.: Yale. University Press.

Parente, Stephen L., and Edward C. Prescott. 2001. Barriers to Riches. Cambridge, MA: MIT Press.

Ram, Rati. 1995. Defense Expenditures and Economic Growth. in Handbook of Defense Economics, v. 1, Keith Hartley and Todd Sandler, eds. New York: Elsevier. pps. 251274.

Reuveny, Rafael and William R. Thompson. 2002. World Economic Growth, Northern Antagonism, and North-south Conflict. Journal of Conflict Resolution, 46 Aug: 484 514.

Romer, Paul. 1990. Endogenous Technological Change. Journal of Political Economy, Vol. 98, No. 5, Part 2: The Problem of Development: A Conference of the Institute for the Study of Free Enterprise Systems. pp. S71-S102.

Sala-i-Martin, Xavier. 1997a. I Just Ran Two Million Regressions. American Economic Review, 87: 2, 178-183. Data available at www.columbia.edu/ xs23.

Sala-i-Martin, Xavier. 1997b. I Just Ran Four Million Regressions. National Bureau of Economic Research Working Paper 6252.

Solow, Robert. 1956. A Contribution to the Theory of Economic Growth. Quarterly Journal of Economics. Vol. 701 pp. 65-94.

Temple, Jonathan. 2000. Growth regressions and what the textbooks don't tell you. Bulletin of Economic Research, Vol. 52, pp. 181-205.

USAID Greenbook. 2008. U.S. Overseas Loans and Grants: Obligations and Loan Authorizations, July 1, 1945-September 30, 2008. http://qesdb.cdie.org/gbk/index.html (accessed February 11, 2010). 
Weede, Erich. 1996. Economic Development, Social Order, and World Politics. Boulder, CO: L. Rienner.

Weede, Erich. 1993. The impact of military participation on economic growth and income inequality: some new evidence. Journal of Political and Military Sociology, 21, 241-258. 


\section{DATA APPENDIX}

\begin{tabular}{|c|c|c|c|c|c|c|}
\hline Country & Code & $\begin{array}{l}\text { Troops } \\
(1950- \\
2000) \\
\end{array}$ & $\begin{array}{c}\text { Log } \\
\text { Troops } \\
\text { (base10) }\end{array}$ & $\begin{array}{l}\text { Presence } \\
\text { (of } \\
\text { Troops) }\end{array}$ & $\begin{array}{c}\text { Troops } \\
\text { per capita } \\
\text { (million) }\end{array}$ & $\begin{array}{c}\text { Log (10) } \\
\text { Military } \\
\text { Aid }\end{array}$ \\
\hline Germany & GER & $10,452,416$ & 7.019 & 269.1 & 127.2 & 3.742 \\
\hline Japan & JPN & $3,942,313$ & 6.596 & 246.2 & 31.1 & 3.820 \\
\hline Korea, Republic of & KOR & $3,340,274$ & 6.524 & 238.8 & 70.7 & 4.520 \\
\hline United Kingdom & GBR & $1,281,627$ & 6.108 & 222.5 & 21.4 & 3.810 \\
\hline France & FRA & 685,083 & 5.836 & 142.4 & 11.3 & 4.430 \\
\hline Philippines & PHL & 673,372 & 5.828 & 194.2 & 8.9 & 3.755 \\
\hline Italy & ITA & 588,255 & 5.770 & 206.6 & 10.2 & 4.154 \\
\hline Panama & PAN & 485,495 & 5.686 & 198.0 & 170.0 & 2.100 \\
\hline Thailand & THA & 380,894 & 5.581 & 140.7 & 6.3 & 3.899 \\
\hline Spain & ESP & 364,752 & 5.562 & 186.9 & 9.1 & 3.945 \\
\hline Turkey & TUR & 284,387 & 5.454 & 186.8 & 4.3 & 4.564 \\
\hline Canada & CAN & 255,206 & 5.407 & 165.5 & 8.3 & 1.844 \\
\hline Iceland & ISL & 152,341 & 5.183 & 174.0 & 541.6 & 0.146 \\
\hline Morocco & MAR & 148,206 & 5.171 & 133.8 & 5.2 & 3.282 \\
\hline Greece & GRC & 142,255 & 5.153 & 168.5 & 13.5 & 4.400 \\
\hline Portugal & PRT & 89,535 & 4.952 & 163.6 & 8.9 & 3.644 \\
\hline Netherlands & NLD & 81,208 & 4.910 & 155.5 & 5.1 & 3.874 \\
\hline Belgium & BEL & 76,003 & 4.881 & 150.1 & 7.4 & 3.873 \\
\hline Austria & AUT & 64,080 & 4.807 & 89.9 & 7.9 & 2.844 \\
\hline Egypt & EGY & 28,767 & 4.459 & 115.5 & 0.4 & 4.555 \\
\hline Australia & AUS & 21,913 & 4.341 & 122.9 & 1.1 & 2.780 \\
\hline Ethiopia & ETH & 19,420 & 4.288 & 84.0 & 0.3 & 3.085 \\
\hline Norway & NOR & 18,901 & 4.277 & 122.2 & 4.2 & 3.723 \\
\hline Iran & IRN & 17,479 & 4.243 & 81.6 & 0.3 & 3.835 \\
\hline Honduras & HND & 15,831 & 4.200 & 95.6 & 2.5 & 2.947 \\
\hline Pakistan & PAK & 14,746 & 4.169 & 95.9 & 0.1 & 3.850 \\
\hline Hong Kong & $\mathrm{HKG}$ & 13,574 & 4.133 & 81.4 & 2.0 & 0.000 \\
\hline Algeria & DZA & 7,252 & 3.861 & 30.6 & 0.2 & 0.491 \\
\hline New Zealand & NZL & 6,682 & 3.825 & 90.7 & 1.7 & 1.274 \\
\hline Brazil & BRA & 6,656 & 3.823 & 102.7 & 0.0 & 3.459 \\
\hline Denmark & DNK & 5,059 & 3.704 & 90.5 & 0.9 & 3.557 \\
\hline Ireland & IRL & 4,173 & 3.621 & 57.8 & 1.1 & 0.041 \\
\hline Dominican Republic & DOM & 3,492 & 3.543 & 69.2 & 0.4 & 2.458 \\
\hline Uruguay & USA & 3,184 & 3.503 & 68.3 & 0.0 & 2.606 \\
\hline Peru & PER & 3,128 & 3.495 & 85.1 & 0.1 & 3.051 \\
\hline Israel & ISR & 3,098 & 3.491 & 88.2 & 0.5 & 4.915 \\
\hline Venezuela & VEN & 3,070 & 3.487 & 88.7 & 0.1 & 2.852 \\
\hline Colombia & $\mathrm{COL}$ & 2,533 & 3.404 & 84.1 & 0.1 & 3.175 \\
\hline Trinidad & TTO & 2,526 & 3.403 & 32.7 & 1.9 & 0.903 \\
\hline Ecuador & $\mathrm{ECU}$ & 2,451 & 3.390 & 80.2 & 0.2 & 2.736 \\
\hline India & IND & 2,438 & 3.387 & 82.6 & 0.0 & 2.850 \\
\hline Mexico & MEX & 2,253 & 3.353 & 75.3 & 0.0 & 2.171 \\
\hline Chile & CHL & 2,240 & 3.350 & 79.5 & 0.1 & 3.008 \\
\hline Indonesia & IDN & 2,206 & 3.344 & 82.4 & 0.0 & 3.285 \\
\hline
\end{tabular}




\begin{tabular}{|c|c|c|c|c|c|c|}
\hline Guatemala & GTM & 2,149 & 3.332 & 75.8 & 0.2 & 2.370 \\
\hline Argentina & $\mathrm{ARG}$ & 1,994 & 3.300 & 79.6 & 0.1 & 3.026 \\
\hline El Salvador & SLV & 1,957 & 3.292 & 77.4 & 0.3 & 3.243 \\
\hline Bolivia & BOL & 1,791 & 3.253 & 76.6 & 0.2 & 2.691 \\
\hline Malaysia & MYS & 1,698 & 3.230 & 63.8 & 0.1 & 2.720 \\
\hline Barbados & $\mathrm{BRB}$ & 1,517 & 3.181 & 48.4 & 5.7 & 1.255 \\
\hline Jamaica & JAM & 1,405 & 3.148 & 44.4 & 0.5 & 1.878 \\
\hline Switzerland & $\mathrm{CHE}$ & 1,346 & 3.129 & 72.2 & 0.2 & 0.000 \\
\hline South Africa & $\mathrm{ZAF}$ & 1,192 & 3.077 & 65.2 & 0.0 & 0.820 \\
\hline Congo, Dem. Rep. & $\mathrm{COG}$ & 1,158 & 3.064 & 55.7 & 0.4 & 2.771 \\
\hline Paraguay & PRY & 1,072 & 3.031 & 65.8 & 0.2 & 2.091 \\
\hline Finland & FIN & 1,037 & 3.016 & 67.2 & 0.2 & 0.415 \\
\hline Sweden & SWE & 1,015 & 3.007 & 65.6 & 0.1 & 0.000 \\
\hline Nicaragua & NIC & 914 & 2.961 & 63.9 & 0.2 & 2.160 \\
\hline Jordan & JOR & 908 & 2.959 & 60.8 & 0.2 & 3.661 \\
\hline Kenya & KEN & 892 & 2.951 & 40.0 & 0.0 & 2.718 \\
\hline Costa Rica & CRI & 775 & 2.890 & 58.1 & 0.2 & 1.877 \\
\hline China & $\mathrm{CHN}$ & 690 & 2.839 & 32.1 & 0.0 & 0.000 \\
\hline Ivory Coast & CIV & 571 & 2.757 & 46.0 & 0.0 & 1.033 \\
\hline Nigeria & NGA & 540 & 2.733 & 44.6 & 0.0 & 1.342 \\
\hline Romania & ROM & 471 & 2.674 & 48.3 & 0.0 & 0.000 \\
\hline Sri Lanka / Ceylon & LKA & 463 & 2.667 & 50.3 & 0.0 & 1.360 \\
\hline Syria & SYR & 420 & 2.624 & 42.3 & 0.0 & 0.114 \\
\hline Senegal & SEN & 375 & 2.575 & 38.9 & 0.0 & 2.010 \\
\hline Ghana & GHA & 349 & 2.544 & 40.6 & 0.0 & 1.276 \\
\hline Luxembourg & LUX & 334 & 2.525 & 40.9 & 0.8 & 0.000 \\
\hline Nepal & NPL & 280 & 2.449 & 35.7 & 0.0 & 1.199 \\
\hline Chad & TCD & 242 & 2.386 & 29.4 & 0.0 & 1.770 \\
\hline Cameroon & CMR & 239 & 2.380 & 30.0 & 0.0 & 1.760 \\
\hline Madagascar & MDG & 231 & 2.365 & 29.6 & 0.0 & 0.991 \\
\hline Bangladesh & BGD & 206 & 2.316 & 22.8 & 0.0 & 1.579 \\
\hline Tanzania & $\mathrm{TZA}$ & 170 & 2.233 & 21.7 & 0.0 & 0.447 \\
\hline Mali & MLI & 164 & 2.217 & 24.3 & 0.0 & 1.384 \\
\hline Niger & NER & 159 & 2.204 & 20.5 & 0.0 & 1.662 \\
\hline Zimbabwe & ZWE & 153 & 2.188 & 17.5 & 0.0 & 1.193 \\
\hline Zambia & ZMB & 150 & 2.179 & 19.5 & 0.0 & 0.462 \\
\hline Seychelles Island & SYC & 139 & 2.146 & 20.3 & 1.7 & 0.431 \\
\hline Gabon & GAB & 102 & 2.013 & 14.6 & 0.1 & 1.533 \\
\hline Uganda & UGA & 96 & 1.987 & 12.9 & 0.0 & 1.270 \\
\hline Guinea & GIN & 91 & 1.964 & 13.3 & 0.0 & 1.338 \\
\hline Mauritius & MUS & 89 & 1.954 & 12.6 & 0.1 & 0.380 \\
\hline Burundi & BDI & 89 & 1.954 & 13.3 & 0.0 & 0.602 \\
\hline Togo & TGO & 88 & 1.949 & 12.5 & 0.0 & 0.415 \\
\hline Mozambique & MOZ & 70 & 1.851 & 10.5 & 0.0 & 1.380 \\
\hline Burkina Faso & BFA & 67 & 1.833 & 9.4 & 0.0 & 1.632 \\
\hline Malawi & MWI & 46 & 1.672 & 9.9 & 0.0 & 1.182 \\
\hline Rwanda & RWA & 3 & 0.602 & 0.8 & 0.0 & 2.034 \\
\hline Lesotho & LSO & 0 & 0.000 & 0.0 & 0.0 & 0.398 \\
\hline Guinea-Bissau & GNB & 0 & 0.000 & 0.0 & 0.0 & 0.756 \\
\hline Gambia, The & GMB & 0 & 0.000 & 0.0 & 0.0 & 0.653 \\
\hline
\end{tabular}


Table 1. Summary of countries ranked by U.S. troops hosted during 1950-2000

\begin{tabular}{llllll}
\hline & \multirow{2}{*}{$\begin{array}{l}\text { Troop-years } \\
(1950-2000,\end{array}$} & \multicolumn{4}{c}{$\begin{array}{c}\text { GDP per capita } \\
\text { (PPP \$, average) }\end{array}$} \\
\cline { 4 - 7 } & average) & 1960 & 2000 & Growth & (St. Dev.) \\
\hline 10 countries with the & & & & & \\
$\quad$ most U.S. troops & $2,219,448$ & 4,916 & 16,413 & $3.25 \%$ & $(1.4)$ \\
Second 10 countries & 132,199 & 5,603 & 16,872 & $2.82 \%$ & $(0.5)$ \\
Third 10 countries & 14,245 & 4,413 & 12,091 & $2.22 \%$ & $(1.5)$ \\
Fourth 10 countries & 3,271 & 5,561 & 13,954 & $2.07 \%$ & $(1.3)$ \\
54 countries with the & 723 & 2,515 & 5,557 & $1.33 \%$ & $(1.5)$ \\
$\quad$ fewest U.S. troops & & & & & \\
All 94 countries & 252,454 & 3,625 & 9,504 & $1.86 \%$ & $(1.5)$ \\
\hline
\end{tabular}

A troop-year is the measure of one soldier based in a country for one year. This table ranks countries in groups of ten from those with the most troop-years during 1950-2000 to those with the fewest. For example, the average country hosted a total of 252,454 U.S. troop-years during the 51 year period. Essentially all nations hosted some number of U.S. troops greater than zero. Only 4 nations hosted no troops among the 185 nations in the Kane (2004) dataset. Of the 94 nations included in regressions in this paper (limited by available GDP data), 91 had troop-years greater than zero. 
Table 2. Correlation between GDP per capita measures and U.S. troop measures $(\mathrm{n}=94)$

\section{GDP per capita}

Growth, 1960-2000 Log Level 2000

Troops 1950-2000

LogTroops (1950-2000)

Presence (sum of annual LogTroops)

LogTroops 1950s

LogTroops 1960s

Troops per capita 1950-2000

LogTroops per capita 1950-2000

Years100

Years 1000
.200

.486

.465

.507

.460

.140

.140

.421

.378
.230

.615

.574

.600

.455

.204

.518

.487

.407

Data for these calculations are derived from the Penn World Tables (Mark 6.1), real GDP per capita, chain weighted using PPP comparisons across countries and Kane (2004) U.S. troop dataset. 
Table 3. Multivariate OLS Equations for National Real GDP per capita Growth, 1960-2000 (n=94)

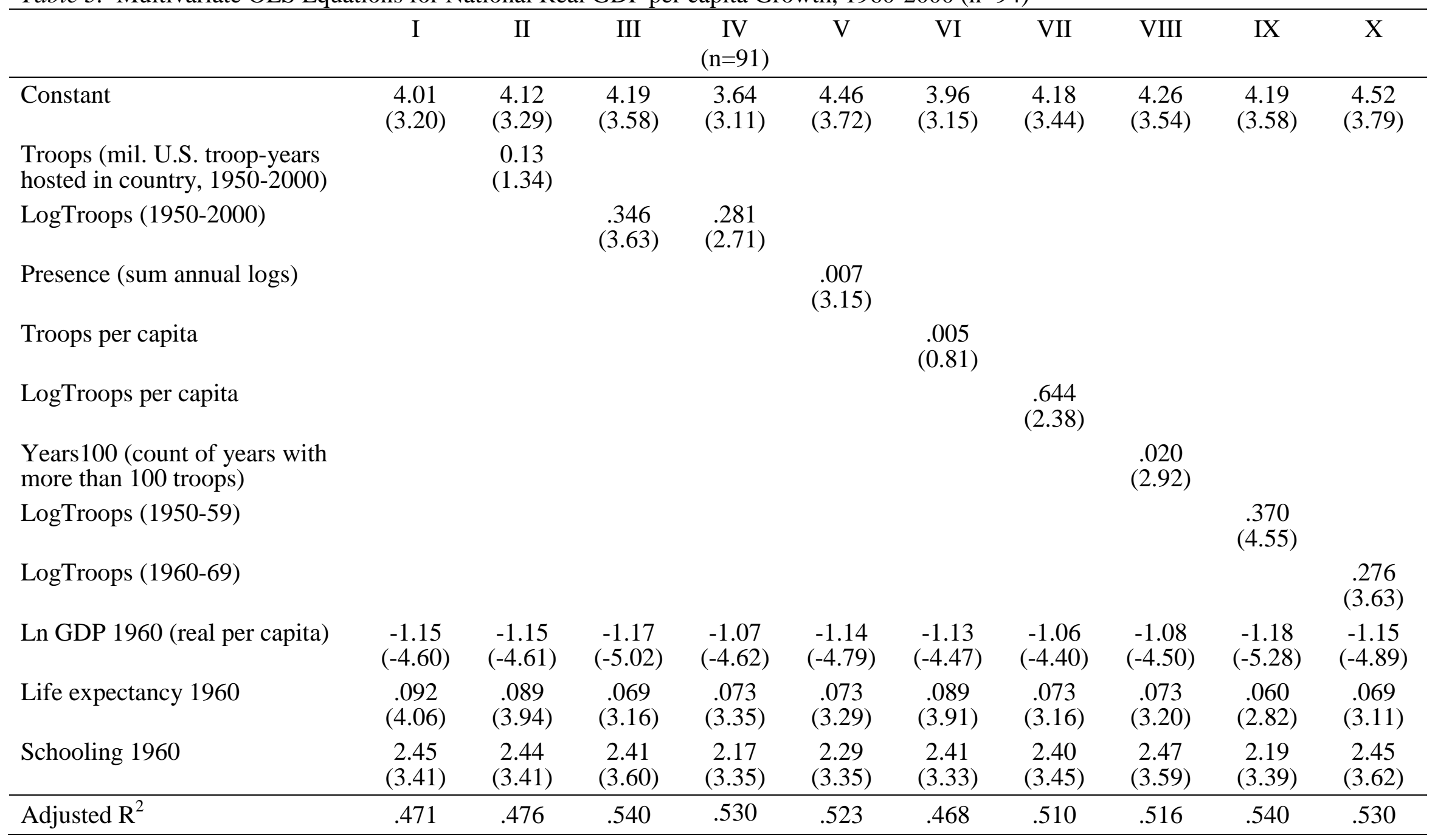

* t-statistics are reported in parentheses.

Equation IV omits outliers Germany, Japan, and South Korea. 
Table 4. Robustness Testing with Multivariate OLS Equations for National Real GDP per capita Growth, 1960-2000

\begin{tabular}{|c|c|c|c|c|c|c|c|c|}
\hline & I & II & III & IV & $\mathrm{V}$ & VI & VII & VIII \\
\hline Constant & $\begin{array}{c}4.50 \\
(3.27)\end{array}$ & $\begin{array}{c}4.88 \\
(4.28)\end{array}$ & $\begin{array}{c}5.22 \\
(4.02)\end{array}$ & $\begin{array}{c}4.89 \\
(3.94)\end{array}$ & $\begin{array}{c}4.65 \\
(3.90)\end{array}$ & $\begin{array}{c}3.28 \\
(2.83)\end{array}$ & $\begin{array}{c}4.25 \\
(3.59)\end{array}$ & $\begin{array}{c}3.90 \\
(3.26)\end{array}$ \\
\hline LogTroops & $\begin{array}{c}.364 \\
(3.34)\end{array}$ & $\begin{array}{c}.306 \\
(3.34)\end{array}$ & $\begin{array}{c}.265 \\
(2.51)\end{array}$ & $\begin{array}{c}.383 \\
(3.94)\end{array}$ & $\begin{array}{c}.378 \\
(3.92)\end{array}$ & $\begin{array}{c}.454 \\
(4.58)\end{array}$ & $\begin{array}{c}.381 \\
(2.94)\end{array}$ & $\begin{array}{c}.289 \\
(2.74)\end{array}$ \\
\hline Ln GDP 1960 (real per cap) & $\begin{array}{c}-1.34 \\
(-5.16)\end{array}$ & $\begin{array}{c}-1.16 \\
(-5.20)\end{array}$ & $\begin{array}{c}-1.19 \\
(-5.18)\end{array}$ & $\begin{array}{c}-1.22 \\
(-5.23)\end{array}$ & $\begin{array}{l}-1.15 \\
(-4.97)\end{array}$ & $\begin{array}{l}-1.04 \\
(-4.61)\end{array}$ & $\begin{array}{c}-1.17 \\
(-4.99)\end{array}$ & $\begin{array}{c}-1.12 \\
(-4.75)\end{array}$ \\
\hline Life expectancy 1960 & $\begin{array}{c}.082 \\
(3.05)\end{array}$ & $\begin{array}{c}.051 \\
(2.33)\end{array}$ & $\begin{array}{c}.065 \\
(2.99)\end{array}$ & $\begin{array}{c}.062 \\
(2.79)\end{array}$ & $\begin{array}{c}.058 \\
(2.56)\end{array}$ & $\begin{array}{l}.065 \\
(2.97)\end{array}$ & $\begin{array}{c}.068 \\
(3.00)\end{array}$ & $\begin{array}{c}.071 \\
(3.22)\end{array}$ \\
\hline Schooling 1960 & $\begin{array}{c}2.25 \\
(2.83)\end{array}$ & $\begin{array}{c}2.25 \\
(3.52)\end{array}$ & $\begin{array}{c}2.23 \\
(3.33)\end{array}$ & $\begin{array}{c}2.59 \\
(3.84)\end{array}$ & $\begin{array}{c}2.45 \\
(3.70)\end{array}$ & $\begin{array}{c}2.62 \\
(3.97)\end{array}$ & $\begin{array}{c}2.45 \\
(3.60)\end{array}$ & $\begin{array}{c}2.34 \\
(3.50)\end{array}$ \\
\hline Equipment Investment & $\begin{array}{c}8.20 \\
(1.38)\end{array}$ & & & & & & & \\
\hline Openness (Years) & & $\begin{array}{l}1.27 \\
(2.99)\end{array}$ & & & & & & \\
\hline Dummy SSA & & & $\begin{array}{l}-6.22 \\
(-1.73)\end{array}$ & & & & & \\
\hline Dummy WAR & & & & $\begin{array}{c}-.389 \\
(-1.57)\end{array}$ & & & & \\
\hline Revolution \& Coups & & & & & $\begin{array}{c}-.783 \\
(-1.62)\end{array}$ & & & \\
\hline Democracy 65 & & & & & & $\begin{array}{l}-.835 \\
(-1.60)\end{array}$ & & \\
\hline Log U.S. Military Aid & & & & & & & $\begin{array}{c}-.047 \\
(-0.39)\end{array}$ & \\
\hline U.S. Economic Aid & & & & & & & & $\begin{array}{l}.00002 \\
(1.27) \\
\end{array}$ \\
\hline Adjusted $\mathrm{R}^{2}$ & .586 & .581 & .551 & .548 & .549 & .602 & .535 & .543 \\
\hline Observations $(\mathrm{n}=)$ & 70 & 84 & 84 & 84 & 84 & 78 & 84 & 84 \\
\hline
\end{tabular}

* t-statistics are reported in parentheses 
Table 5. Correlation between U.S. AID measures and U.S. troop measures $(n=94)$

\section{MilAID EconAID LogMilAID LogEconAID}

\begin{tabular}{lcccc}
\hline Troops 1950-2000 & 0.135 & 0.247 & 0.259 & 0.221 \\
LogTroops 1950-2000 & 0.360 & 0.394 & 0.653 & 0.386 \\
Presence (sum of annual logs) & 0.385 & 0.421 & 0.673 & 0.396 \\
LogTroops 1950-59 & 0.330 & 0.372 & 0.595 & 0.362 \\
LogTroops 1960-69 & 0.343 & 0.392 & 0.675 & 0.366 \\
Troops per capita 1950-2000 & 0.008 & 0.014 & -0.06 & 0.023 \\
LogTroops per capita 1950-2000 & 0.244 & 0.202 & 0.354 & 0.195 \\
Years100 & 0.322 & 0.279 & 0.58 & 0.286 \\
Years1000 & 0.332 & 0.308 & 0.495 & 0.354
\end{tabular}

Data for these calculations are derived from the USAID Greenbook (2008) and Kane (2004) U.S. troop dataset. 
Table 6. Multivariate OLS Equations for National Real GDP per capita Growth, 1960-2000, omitting outliers Germany, Japan, and South Korea

\begin{tabular}{lccc}
\hline & I & II & III \\
\hline Constant & 3.64 & 4.62 & 3.89 \\
& $(3.11)$ & $(3.20)$ & $(3.27)$ \\
LogTroops & 0.281 & & \\
& $(2.71)$ & & \\
LogTroops (1950-59) & & 0.319 & \\
& & $(3.61)$ & \\
LogTroops (1960-69) & & & 0.220 \\
& & & $(2.53)$ \\
Ln GDP 1960 (real per capita) & -1.07 & -1.10 & -1.05 \\
& $(-4.62)$ & $(-4.87)$ & $(-4.51)$ \\
Life expectancy 1960 & 0.073 & 0.064 & 0.073 \\
& $(3.35)$ & $(3.01)$ & $(3.32)$ \\
Schooling 1960 & 2.17 & 2.00 & 2.18 \\
& $(3.35)$ & $(3.11)$ & $(3.32)$ \\
\hline Adjusted ${ }^{2}$ & 0.530 & 0.559 & 0.524 \\
Observations (n=) & 91 & 91 & 91 \\
\hline
\end{tabular}

$* \mathrm{t}$-statistics are reported in parentheses 
Table 7. Nonlinear estimate of the effect of U.S. Troops on Economic Growth

A. Regression Results. Dependent Variable: GDP per capita, 1990-2000 (n=94)

\begin{tabular}{|c|c|}
\hline LogTroops & $\begin{array}{l}1.53 \\
(2.13)\end{array}$ \\
\hline LogTroops $^{2}$ & $\begin{array}{l}0.12 \\
(2.22)\end{array}$ \\
\hline LogTroops*Log GDP 1960 & $\begin{array}{l}-0.27 \\
(-2.17)\end{array}$ \\
\hline
\end{tabular}

Coefficients are from a regression identical to Table 3 , but also including a quadratic and interaction term. Other coefficients not reported. t-statistics are reported in parentheses.

B. Simulation: Annual growth rate effect of U.S. Troops, organized by country GDP per capita level in 1960 and size of troop deployment during 1950-2000.

\begin{tabular}{lllll} 
& \multicolumn{4}{l}{ Annual Average U.S. Troops } \\
\cline { 2 - 5 } & Handful & Tens & Hundreds & Thousands \\
Poorest Countries & $0.24 \%$ & $1.44 \%$ & $3.60 \%$ & $6.72 \%$ \\
Lower-Middle & $-0.30 \%$ & $0.36 \%$ & $1.98 \%$ & $4.56 \%$ \\
Upper-Middle & $-0.84 \%$ & $-0.72 \%$ & $0.36 \%$ & $2.40 \%$ \\
Richest & $-1.38 \%$ & $-1.80 \%$ & $-1.26 \%$ & $0.24 \%$
\end{tabular}

Coefficients in Part B show the predicted effect of LogTroops on economic growth using coefficients from Part A. Rows illustrate the effects on different types of countries ("Poorest"=1960 log GDP per capita of 6, "Lower-Middle"=7, "Upper-Middle"=8, "Richest"=9). Columns are for values of LogTroops: "Handful"=LogTroops of 2, While "Dozens," "Hundreds," and "Thousands" illustrate LogTroops of 4, 6, and 8 respectively. Both log troop and log GDP values represent the span of values in our dataset. 
Table 8. Time and country fixed-effect panel estimates for National Real GDP per capita (GDPP) Growth, one- and two-decade panels, 1960-2000

\begin{tabular}{lll}
\hline Dependent Variable: & $\begin{array}{c}\text { GDPP growth } \\
t \text { to } t+10\end{array}$ & $\begin{array}{l}\text { GDPP growth } \\
t \text { to } t+20\end{array}$ \\
\hline LogTroops & $0.504^{* * *}$ & $0.578^{* * *}$ \\
$t$ - 10 to $t$ - 1 & $(2.65)$ & $(2.67)$ \\
Primary schooling & $0.635^{*}$ & 0.448 \\
year $t$ & $(1.83)$ & $(1.03)$ \\
ln GDP & $0.191^{*}$ & $0.277^{* *}$ \\
year $t$ & $(1.76)$ & $(2.17)$ \\
\hline \# of observations & 302 & 150 \\
Mean $\mathrm{R}^{2}$ & .433 & .672 \\
\hline
\end{tabular}

Note: Time and country fixed effects included in this non-overlapping, unbalanced panel estimate. t-statistics in parentheses. * indicates $10 \%$, ** indicates $5 \%$, and $* * *$ indicates $1 \%$ significance levels. 
Figure 1. U.S. Troops deployed abroad annually, by region, 1950-2000

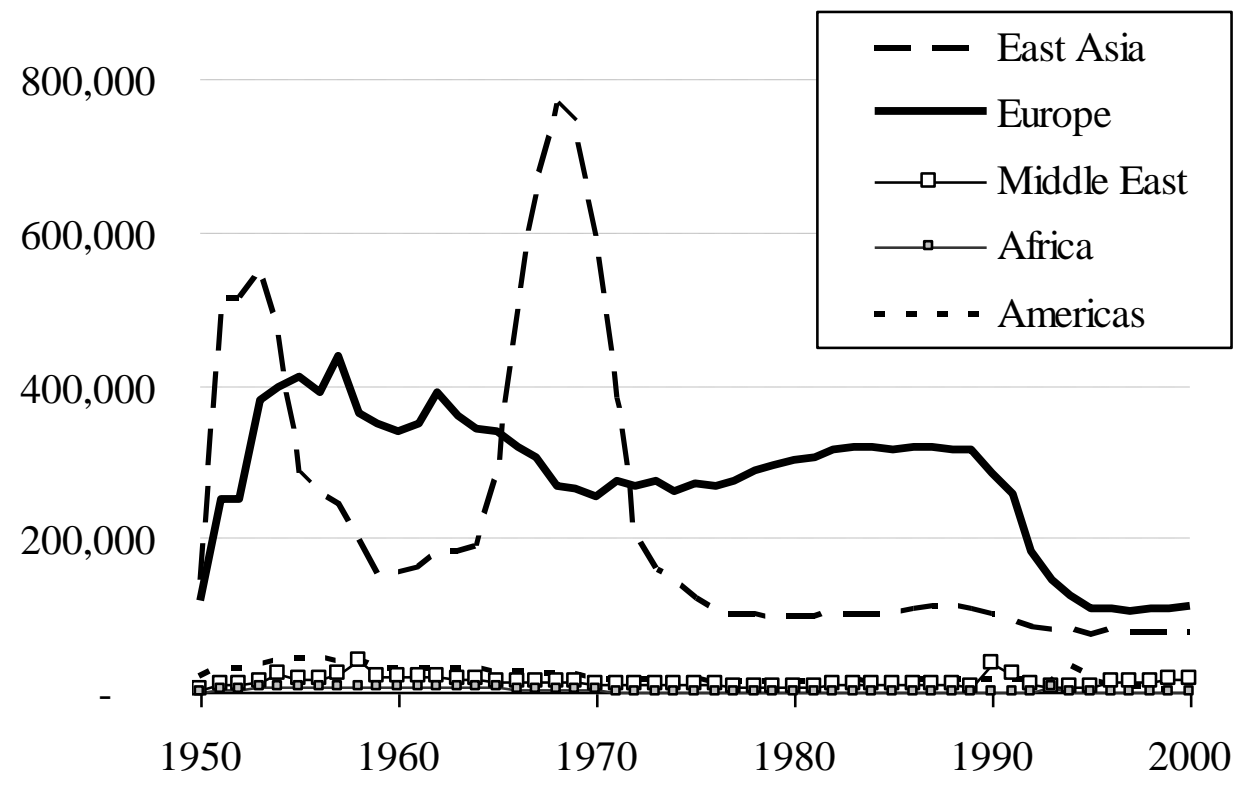

Source: Kane (2004) based on annual records from Department of Defense, DIOR. 
Figure 2. Scatterplot of GDP Growth (average annual, real per capita, 1960-2000) and LogTroops (log value of U.S. troops deployed, 1950-2000), for 94 countries.

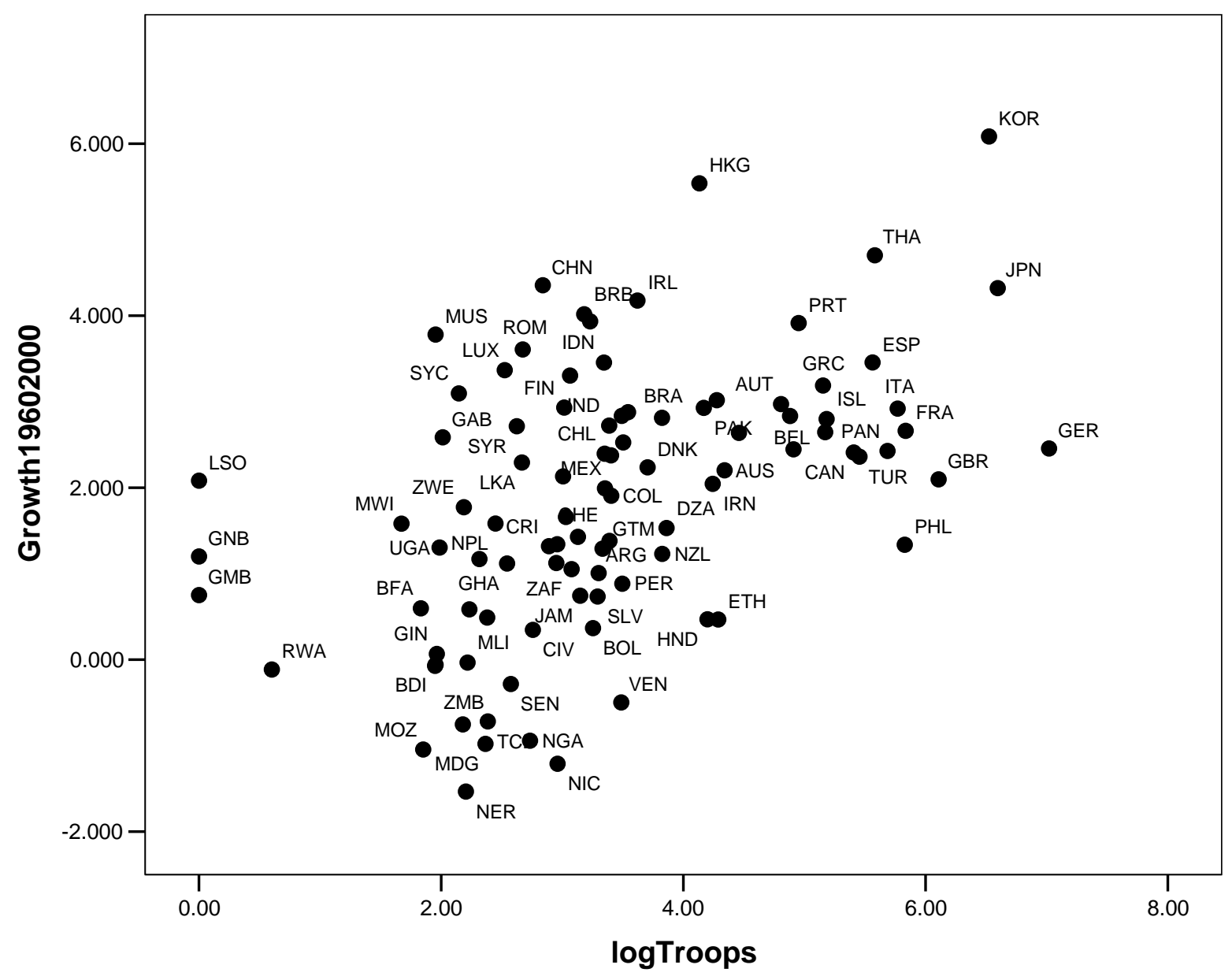


Figure 3. LogTroops and Fitted GDP Growth, 1960-2000

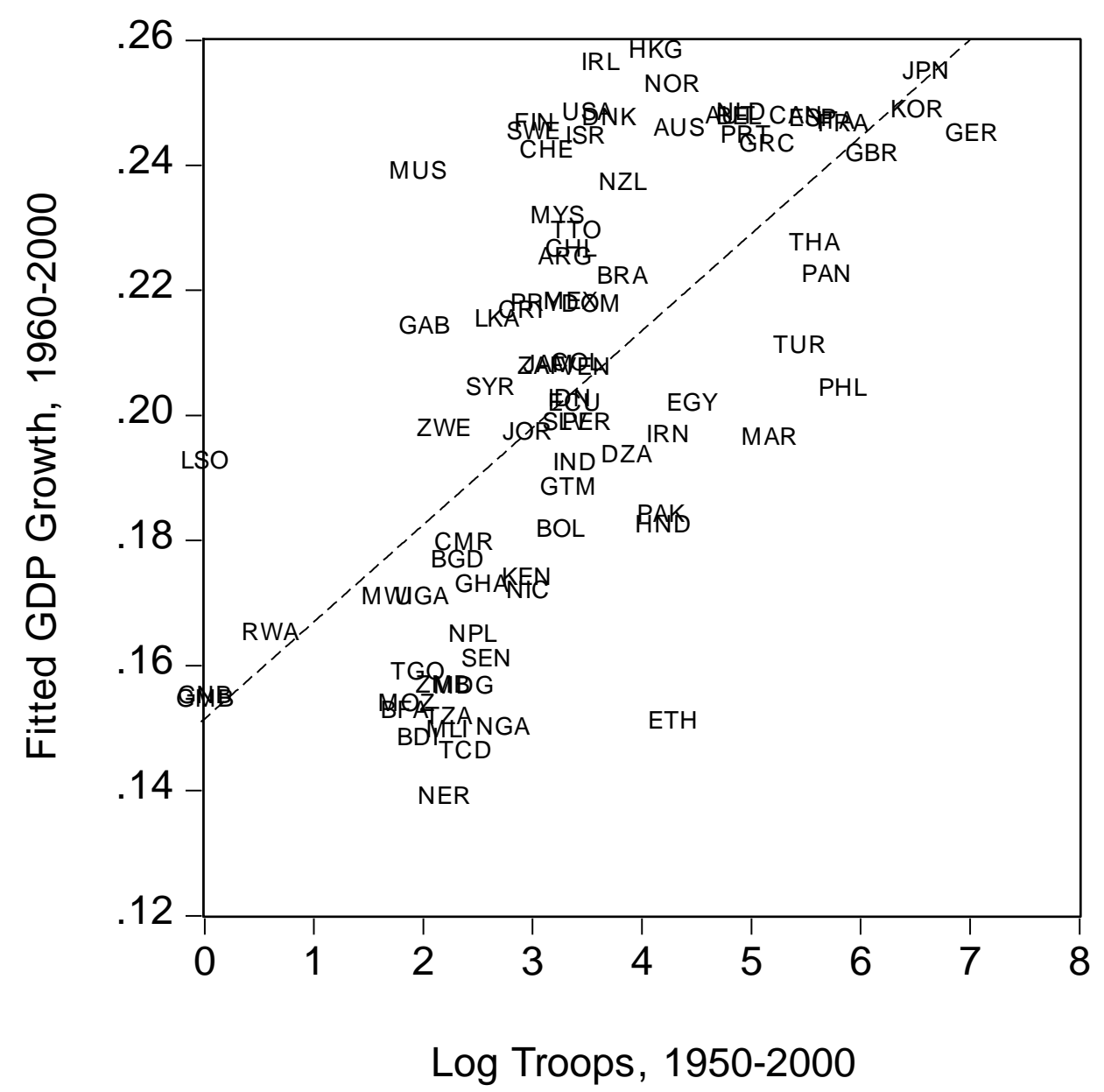

Note: Y-values are residuals from the LogTroops regression in Table 3, omitting fitted values from LogTroops. Controls include $1960 \log$ GDP per capita, 1960 primary education, and 1960 life expectancy. Least-squares regression line is also included; the partial $\mathrm{R}^{2}$ is 0.42 . 


\section{NOTES}

${ }^{1}$ The limiting factor is comparable data on economic growth. For example, since economic growth data on Vietnam is unavailable in the Penn World Tables, that large troop deployment is not included in our analysis. This is especially unfortunate because Vietnam seems to be growing faster than nearby countries Laos and Cambodia which had no comparable U.S. presence.

${ }^{2}$ Note that the use of $\log$ Troops diminishes the power of fast-growing outliers such as Germany which had over 10 million troop-years and Japan which had over four million troop-years.

${ }^{3}$ The variable $\log$ troops was generated by taking the $\log$ of Troops plus 1 , since $\log (0)$ is negative infinity and $\log (1)$ is zero. We utilize base $10 \log$ s rather than natural logs so that estimates of the troops-growth relationship can be interpreted in order-of-magnitude terms. Note that whatever log root is used will have the exact same econometric effect.

${ }^{4}$ Likewise, one extra year with over 1000 soldiers has roughly the same effect $(\mathrm{t}=2.42)$.

${ }^{5}$ Hoover and Perez (2004) offer a qualified endorsement of extreme bounds in cross-country growth regressions, while Temple (2001) is more enthusiastic. Both offer good discussions of the methodological issues involved.

${ }^{6}$ Sala-i-Martin's top 21 variables includes the following, in order: Equipment Investment + , Number of Years Open Economy +, Fraction Confucian +, Rule of Law +, Fraction Muslim +, Political Rights +, Latin America Dummy -, Sub-Saharan Africa Dummy -, Civil Liberties +, Revolutions and Coups -, Fraction of GDP in Mining +, Std. Dev. of Black Market Premium -, Fraction of GDP in Primary Exports in 1970 -, Degree of Capitalism +, War Dummy -, Non-Equipment Investment +, Absolute Latitude +, Exchange Rate Distortions -, Fraction Protestant -, Fraction Buddhist + , Fraction Catholic - .

${ }^{7}$ Including a war dummy does shed light on the natural question of whether there are different types of troops, or if their impact varies based on the local environment. Superficially, the regression suggests that the presence of the American military is more useful than peace for enhancing progrowth institutions. A better interpretation might be that peace is important, but not necessary or sufficient at promoting economic growth.

${ }^{8}$ USAID maintains an online record at http://qesdb.cdie.org/gbk/index.html of all economic and military aid sent overseas, by country and by year, from 1946 to the present.

${ }^{9}$ Nonlinearities may exist for non-troops variables, but the exploration of nonlinearities is both uncommon in empirical growth research and beyond the scope of this paper, the first on the topic of the troops-growth relationship.

${ }^{10}$ Easterly (2002) describes the optimism about Ghana, which in 1957 became the first nation in subSaharan Africa to achieve independence. He writes that "many of the world's economists [believed that] assistance to Ghana would yield very high returns." The head of the World Bank's economics department believed in 1967 that Ghana had a potential annual economic growth rate of 7 percent. 